\title{
METODA HISTORYCZNA W TEOLOGII BIBLIJNEJ XX WIEKU
}

Teologia biblijna ${ }^{1}$ stanowi dziś $w$ biblistyce dyscyplinę odrębną ze względu na metodę a następuje po introdukcji oraz egzegezie. Doniosłość teologii biblijnej stwierdza szereg dokumentów Magisterium Kościoła $\mathrm{z}$ ostatniego $50-\mathrm{lecia}^{2}$, uważając ją za niezbędną już nawet $\mathrm{w}$ formacji intelektualnej przyszłych kapłanów. Stąd jej katedra z reguły obecna jest na wydziałach uniwersytetów. Wśród uczonych katolickich teologia biblijna jako wyodrębniona i już tak nazywana liczy sobie ponad sto lat istnienia. W tym czasie dokonał się jej daleko posunięty rozwój, którego wyniki częściowo wykaże niniejszy artykuł.

Zadaniem teologii biblijnej jest usystematyzować całokształt nauki objawionej w Piśmie Świętym, nie wykraczając poza jego dane. A są nimi: sam tekst poddany szczegółowej egzegezie według metod dzisiejszej filologii biblijnej oraz tzw. kategorie biblijne. Tak dziś określają specjaliści prawidłowo wysnute $\mathrm{z}$ tekstu świętego pojęcia, nie mające jednak tam własnych precyzyjnych terminów. Taką kategorią jest np. używana w dokumentach Drugiego Soboru Watykańskiego nazwa „plan” lub „dzieje zbawienia”.

Podczas gdy egzegeza Pisma Świętego drogą szczegółowej analizy wyrazów i zdań ustala sens tekstu natchnionego, teologia biblijna stanowi dla niej niejako wyższe piętro. Dokonuje mianowicie syntezy i klasyfikacji treści podanych w pisanym Słowie Bożym jako źródle Objawienia. Dążenie do ta-

${ }_{2}^{1}$ Termin ten ukuł protestant K. Heymann $(\uparrow 1708)$.

${ }^{2}$ Por. Papieska Komisja Biblijna, Instructio de S. Scriptura recte docenda, z dnia $13 \mathrm{~V}$ 1950, AAS 42 (1950) 502, Enchiridion biblicum ${ }^{4}$ (1961) 594. Cytując ten dokument Vaticanum II, kładzie nacisk na to, by alumni obok dokładnego zapoznania się z metodą egzegezy, uświadomili sobie „najważniejsze tematy Objawienia Bożego", co suponuje posługiwanie się metodami teologii biblijnej, bez niej bowiem nie da się zrealizować postulatu: „Ze szczególną starannością należy kształcić alumnów w zakresie Pisma świętego, które winno być dusza całej teologii" (Dekret o formacji kapłańskiej - Optatam totius, n. 16). Ostatnie określenie zostało powtórzone następnie w Konstytucji Apostolskiej o Uniwersytetach i Wydziałach Kościelnych Sapientia Christiana, z dnia 24 IV 1997, art. 67 §1 (AAS 71 [1997] 491n).

${ }^{3}$ Pionierami wtedy byli P. Scholz, H. Zschokke, Th. Simar. 
kiej całościowej syntezy nie oznacza bynajmniej pretensji do zastapienia sobą całej teologii. Teologia biblijna ma dla całej teologii stanowić jedynie pierwszy i niezastapiony fundament, na którym potem winny się wznosić wszystkie wyżej wyliczone jej działy. Stanowi więc teologia biblijna konieczne ogniwo łączące egzegezę szczegółową tekstu biblijnego z rozwiniętą w pełni teologią, najszerzej pojętą, tak co do treści (a więc: $\mathrm{z}$ teologią dogmatyczna, moralna, ascetyczną i mistyczna), jak co do stosowanych metod (a więc: $\mathrm{z}$ teologią pozytywną lub spekulatywna, czy - jak częściej dziś się określa - z historyczną lub doktrynalna).

Intensywny rozwój biblistyki - równoległe zjawisko do odnowy biblijnej w Kościele i na całym świecie - zaznaczył się również wyraźnym postępem w dziedzinie teologii biblijnej. Wynik tego postępu można zauważyć we współcześnie uznawanym rozczłonkowaniu jej działów:

1) teologia Starego Testamentu w ramach historycznych jej warstw, 2) teologia Starego Testamentu jako wynik relektury tekstów dokonanych w Nowym Testamencie przez apostołów i innych jego pisarzy, 3) ściśle nowotestamentowa teologia uwzględniająca warstwy źródeł i rozwój doktryny w czasie od powstania pierwszego zapisu do ostatniego, 4) kościelna teologia Nowego Testamentu - z włączonymi do niej danymi Tradycji ${ }^{4}$.

Powyższy podział stanowi zarazem ilustrację zwycięstwa metody historycznej w teologii biblijnej, wprowadzając stopniowo i harmonijnie do dalszych etapów rozwoju całej teologii. Ale doniosłość tego zwycięstwa można ocenić tylko przez ukazanie jej stadium początkowego.

Rzeczywiście zupełnie inne było pierwotne ujęcie teologii biblijnej, zwane niekiedy apologetycznym. Trafniej jednak byłoby nazywać to ujęcie uzasadniającym ${ }^{5}$. Według niego zadaniem teologii biblijnej było dostarczanie argumentów biblijnych dla teologii w ogóle, i to drogą zestawiania odpowiednio już interpretowanych tekstów Pisma Świętego. Te miały służyć jako dowody dla gotowych już tez dogmatyki lub zasad teologii moralnej, ascetycznej itd. Było to ujęcie - typu jakby archiwalnego. Określić by je można używając klasycznych terminów ze wstępu do teologii: thesaurus locorum theologicorum e S. Scriptura ${ }^{6}$.

Zaletą tego ujęcia była jego praktyczna użyteczność dla specjalistów w działach teologii, dla dogmatyków, moralistów i ascetologów. Ułatwiało ono bowiem im prędkie znalezienie pierwszego i naczelnego $\mathrm{z}$ argumentów dla dowodzonych tez czy zasad. Ale niosło ono także ze soba szereg niebezpieczeństw, których przyczyną był swoisty anachronizm, grożący pewnym uproszczeniem, zniekształceniem lub niedostatecznym wykorzystaniem danych biblijnych. Anachronizm polegał na tym, że nie liczono się z faktem rozwoju teologii. Na dwa następstwa wystarczy zwrócić uwagę.

\footnotetext{
${ }^{4}$ Por. J. R a $\mathrm{z}$ i n g e r, Offenbarung und Überlieferung, Wien 1965, s. 42-44.

${ }_{6}^{5}$ Jest to moja propozycja.

6 Klasycznym przykładem tego pierwotnego ujęcia był ceniony podręcznik: F. C. C e up pens, Theologia biblica, Torino-Roma 1959, w pięciu tomach. Układ treści tego dzieła odpowiadał traktatom rozwiniętej i usystematyzowanej teologii.
} 
Rozwinięta teologia współczesna operuje pojęciami i kategoriami myślenia, które rozwijając się w ciągu wieków wchłonęły pojęcia takiej czy innej filozofii. Myślenie teologów, wprawdzie przez to wzbogacało się o nowe elementy, ale siła rzeczy jakoś się oddalało od pojęć i kategorii autorów natchnionych. U nich bowiem poszczególne terminy nie oznaczały dokładnie tego samego, co potem rozumiano (niech przykładem będą „ciało" i „duch" czy „dusza”), a wzajemne proporcje i zależności poszczególnych prawd były u nich inne, niż później rozwinęła teologia głównie polemiczna (wystarczy tu wspomnieć choćby doniosłość zmartwychwstania Chrystusa w myśli św. Pawła $\mathrm{w}$ porównaniu $\mathrm{z}$ miejscem tej prawdy $\mathrm{w}$ dawnych podręcznikach dogmatyki). Dopiero uwzględnienie tych danych pierwotnych, nie wykorzystanych dotąd, wnosi do teologii bardzo pożądaną świeżość.

Teologia w ciagu wieków rozwijała się przeważnie w ogniu kontrowersji. To, co nie było kwestionowane, nie było też debatowane ani potem definiowane. I tak np. podstawowa prawda o Ciele eklezjalnym (zazwyczaj się mówi: mistycznym) Chrystusa przeleżała mało komentowana na samym dnie skrzyni Kościoła aż do czasów Piusa XII.

Te braki podały w wątpliwość całe to pierwotne ujęcie teologii biblijnej, to jej podporządkowanie całkowite rozwiniętej teologii. Taka służebna rola teologii biblijnej musiała z czasem ulec - całkiem słusznie - radykalnej zmianie. Zastąpiono ją właśnie metodą historyczną. Dlaczego taką?

Najprostszą odpowiedzią jest powołanie się na to, z czego zdawali sobie sprawę już Ojcowie Kościoła jako teologowie i duszpasterze jednocześnie: Objawienie ma swoją historię ${ }^{\dagger}$. Rozwijało się ono bowiem w ciagu długich wieków, korzystając $\mathrm{z}$ idei, jakie mieli jako ludzie autorzy natchnieni. To właśnie historia kształtowała umysły pisarzy natchnionych i tym samym wpływała na ich sformułowania wyrażane w pismach. Kategorie myślenia tych hagiografów są niezwykle doniosłe dla wykrycia pełnej myśli natchnionej, skoro Drugi Sobór Watykański postawił nam, biblistom, zadanie: „Ponieważ Bóg w Piśmie św. przemawiał przez ludzi, na sposób ludzki, komentator Pisma św. chcąc poznać, co On zamierzał nam oznajmić, powinien uważnie badać, co hagiografowie rzeczywiście chcieli wyrazić i co Bogu spodobało się ich słowami ujawnić"8. Pierwszy, niezbędny trud wniknięcia w świat myśli autora natchnionego możliwy oczywiście tylko za cenę wprowadzenia metod historycznej i filologicznej. Ten trud jest - jak widać - niezbędnym warunkiem dotarcia do Objawienia.

Ale jeszcze coś więcej w tej sprawie trzeba wziąć pod uwagę z głosów Tradycji. Podział na teologię Starego i Nowego Testamentu ma sens nie tylko bibliograficzny. Przedmiotem egzegezy i teologii biblijnej Nowego Testamentu jest objawienie ostateczne dokonane w Jezusie Chrystusie jako

${ }^{7}$ Por. Ir ene usz, Adv. haer. IV, 38, 1-2; Jan Chryzostom, De paenit. hom. 6 PG 49, 320; Grzegor z z Nazjanzu, Or. th., 5, 26 PG 36, $131 \mathrm{n}$.

${ }^{8}$ Powyższe orzeczenie następuje w Konstytucji Dei verbum (KO 11), po cytowanych kolejno wielkich encyklikach biblijnych wieku XIX i XX: Providentissimus Deus Leona XIII, Spiritus Paraclitus Benedykta XV i Divino afflante Spiritu Piusa XII. 
„kresie”, który „wypełnia” to, co Bóg zapowiedział w Starym Testamencie (por. Mt 5, 17; Rz 10, 4; Hbr 1, 12). Taką wewnętrzną zależność dwóch Testamentów lapidarnie ujął św. Augustyn w adagium: „In Vetere Novum latet, et in Novo Vetus patet"9. Niepodobna prawidłowo uprawiać teologii Nowego Testamentu, nie uwzględniając etapu poprzedniego - Prawa, Proroków i Mędrców. Z drugiej strony - suma osiąnięć teologii biblijnej Starego Testamentu nie zdoła sama przez się wytłumaczyć do końca danych Nowego. Te ostatnie bowiem dalece wykraczaja poza skarbiec doktrynalny tamtego wstępnego etapu. Nowy Testament, będąc kontynuacja, jest zarazem przekroczeniem dawnego stadium niepełnego. Zwarta całość jednego jedynego zbawczego planu Boga rozwijała się i ujawniała powoli w ciagu dziejów Objawienia. Zasada typologii ujmowana przez specjalistów w formie Augustynowego „latet - patet” uwzględnia tę historię zarazem ją przekraczając. Snuje bowiem wnioski $\mathrm{z}$ tego faktu, że nad ludzkimi autorami i przez nich działa jeden Autor - Duch Święty. Takie wnioski nie mogły być przedtem przewidziane na drodze badań tylko historycznych.

To, co zostało wyżej powiedziane o długim procesie dziejowym Objawienia, ma też - $\mathrm{z}$ zachowaniem proporcji - zastosowanie do pism samego Nowego Testamentu, choć okres ich powstawania obejmuje, zaokraglając liczby, półwiecze - mianowicie to drugie w I wieku naszej ery. Choć trwały krótko w porównaniu z okresem powstawania Starego Testamentu, były to jednak czasy szczególne. W tych właśnie czasach obfite dary charyzmatyczne Ducha Świętego, a w tej liczbie biblijna theopneustia, miały do przewalczenia opory ideowe tak judaizmu, jak pogańskiego hellenizmu. Ale $\mathrm{z}$ drugiej strony pozytywne elementy środowiska, w którym miała ewangelia zdobywać wyznawców, także domagały się jakiegoś wchłonięcia, by stał się w ogóle możliwy dialog ze słuchaczami kerygmatu apostolskiego. Tego rodzaju polemika i konieczność przystosowania się do warunków środowiskowych u pisarzy Nowego Testamentu znajdowały swój wyraz tak w problematyce, jak w terminologii stosowanej przez jego autorów. Wykrywanie tych procesów domagało się badań historycznych nad milieu, a filologicznych - nad samym tekstem.

Te wszystkie wymogi i wiele gotowych osiagnięć zwłaszcza egzegetów protestanckich stosujących metodę wyłącznie historyczną sprawiły, że mniej więcej od połowy naszego kończącego się stulecia zaczęły się już ukazywać katolickie opracowania teologii biblijnej według metody historycznej ${ }^{10}$. Dziś całkowicie ona juź wyparła dawne ujęcie.

Co więcej - hadania tak diachroniczne (co z czego wyplywa?), jak synchroniczne (co na co współcześnie oddziałuje?) ${ }^{11}$, przeprowadzone w zakre-

9 „Nowy Testament kryje się w Starym, a Stary w Nowym się wyjaśnia": Quaestiones in Heptateuchum 2, 73 PL 34, 263 CSEL 28, 2, 141.

${ }_{10}$ Prekursorami jej byli M. Meinertz i J. Bonsirven ze swymi podręcznikami, R. Schnackenburg w wielu dziełach, a najwięcej do jej uzasadnienia metodologicznego przyczynił się w swoich licznych publikacjach S. Lyonnet.

${ }^{11}$ Tej nomenklaturze dał początek w zakresie teologii Starego Testamentu G. von Rad. 
sie teologii biblijnej, dały wyniki nieoczekiwanie bogate. Okazało się, że teologami biblijnymi w mniejszym lub większym stopniu byli już sami natchnieni pisarze. Oni bowiem nie tylko referowali, lecz także interpretowali życie, wypowiedzi i dzieło Jezusa Chrystusa systematyzując je w pewien sposób, i to w myśl swoich własnych idei naczelnych. Dawno już zauważono nieco różniące się od siebie, a przecież równie natchnione, koncepcje teologiczne w pismach Pawłowych i Janowych. Ostatnio jednak dzięki osiagnięciom metody historii redakcji i badaniom struktury tekstu zauważono wyraźniej pewne idee teologiczne także w ewangeliach synoptycznych, nawet u tylko pozornie najprostszego ewangelisty - Marka.

Do naczelnych więc zadań pracy teologa biblijnego w zakresie Nowego Testamentu należy ustalenie rzeczywistego wpływu kulturowego środowiska na hagiografów. $Z$ drugiej strony bezdroża, na jakie zeszła swego czasu metoda szkoły historyczno-religijnej na skutek swojej jednostronności, nakazują pewną ostrożność także przy posługiwaniu się metodą historyczną $w$ tej dziedzinie, gdyż i ta metoda ma swoje granice w egzegezie ${ }^{12}$.

Sumując zalety nowego ujęcia należy wymienić to, że odpowiada ono powszechnemu dziś dążeniu do tego, co pierwotne i autentyczne, a zarazem trzyma się tradycji Ojców Kościoła. Nic dziwnego, że nowe ujęcie, historyczne, wyparło tamto poprzednie jako zbyt ciasne.

12 Por. A. Jankowski, Zagrożenia współczesnej chrystologii biblijnej, AnCrac 17 [1985] 245-252. Podsumowuje pozytywną ocenę metody historyczno-krytycznej w biblistyce, zaznaczając zarazem jej ograniczenia, ostatnia instrukcja: Commission Biblique Pontificale, L'interprétation de la Bible dans l'Eglise, Città del Vaticano 1993, s. 32n. 